WOJCIECH WITKOWSKI

(Lublin)

\title{
Szczytna prudenta godność - „Themis Polska” i twórczość w niej Aleksandra Thisa
}

\author{
Ruhmreiche prudenta Würde \\ - ,Themis Polska" und die Artikel von Aleksander This \\ in dieser Zeitschrift
}

1. Redakcja „Themis Polskiej” - pierwszego polskiego periodyku naukowego $\mathrm{z}$ zakresu prawa (1828-1830). 2. Twórcy i wydawcy czasopisma. Charakterystyka profilu i zawartości czasopisma. 3. Twórczość Aleksandra Thisa na łamach „Themis Polskiej” - cechy ogólne. 4. Publikacje Aleksandra Thisa na temat prawa $\mathrm{i}$ procesu cywilnego - dogmatyzm i ścisłe związki z jurysprudencją francuską. 5. Aleksander This prekursorem zasady użyteczności prawa.

1. Redaktion „Themis Polska” - der ersten polnischen wissenschaftlichen Zeitschrift im Bereich des Rechts (1828 - 1830). 2. Gründer und Herausgeber der Zeitschrift. Charakteristik des Profils und des Inhalts der Zeitschrift. 3. Artikel von Aleksander This in der "Themis Polska" - allgemeine Merkmale. 4. Werke von Aleksander This über das Zivilrecht und den Zivilprozess

- Dogmatismus und enge Verbindung mit der französischen Jurisprudenz. 5. Aleksander This als Pionier der Prinzipien für die Nützlichkeit des Rechts.

W latach 1828-1830 w Warszawie, stolicy Królestwa Polskiego, wydawany był miesięcznik pod tytułem „Themis Polska, czyli pismo nauce i praktyce prawa poświęcone". W sumie ukazało się 30 zeszytów czasopisma, bowiem w 1828 r. pismo ukazywało się raz w miesiącu, w 1829 r. - w co drugim, by w roku 1830 stać się znowu miesięcznikiem. Był to pierwszy w Polsce periodyk naukowy z zakresu prawa. Pismo przyjęło za dewizę maksymę $Q u i$ juris nodos legumque aenigmata solvat zaczerpniętą od rzymskiego poety Juvenalisa.

Myśl założenia fachowego periodyku powstała w środowisku absolwentów Wydziału Prawa ówczesnego Uniwersytetu Warszawskiego (1816-1831) i pismo mimo braku oficjalnych powiązań było w istocie trybuną Wydziału Prawa, a równocześnie wykładnikiem stanu ówczesnej nauki prawa w Polsce 
rozwijającej się w sposób swoisty, wykorzystującej nader ostrożnie wzory obce, znane dobrze prawnikom polskim ${ }^{1}$.

Trzeba tu zaznaczyć, iż lata dwudzieste XIX stulecia dały istotny początek przemianom pokoleniowym w kręgach prawniczych Królestwa Polskiego. Starszą generację tworzyli ciągle jeszcze aktywni uczeni i profesorowie Uniwersytetu Warszawskiego, a obok nich wybitni praktycy sądowi - wykształceni głównie w uczelniach obcych, ale i w Uniwersytecie Krakowskim bądź Szkole Prawa Księstwa Warszawskiego. Wśród nich warto wymienić Jana Wincentego Bandtkie-Stężyńskiego, Wacława Aleksandra Maciejowskiego czy twórców polskich przepisów hipotecznych z lat 1818 i 1825 - Antoniego i Onufrego Wyczechowskich. Jednak po roku 1820 w coraz wyraźniejszy sposób zaczęła zaznaczać swoją obecność nowa grupa młodych prawników - u progu kariery w wymiarze sprawiedliwości i jednocześnie prezentująca wyraźne ambicje naukowe. Będą to ludzie, co charakterystyczne, pochodzący $\mathrm{z}$ różnych warstw społecznych, a w efekcie tworzący ówczesne kadry inteligencji polskiej. Na taki nowy obraz rekrutacji spolecznej do zawodu prawnika znacząco wpłynęła otwarta polityka władz Uniwersytetu Warszawskiego niekierująca się pochodzeniem stanowym mlodzieży ${ }^{2}$.

Przedstawiciele tego nowego pokolenia prawniczego założyli i prowadzili redakcje „Themis Polskiej”. W gronie jej redaktorów znalazło się 15 osób, a więc było to kolegium dość liczne. Wśród nich tylko trzech najstarszych było absolwentami uczelni pozawarszawskich. Byli to mianowicie: Tomasz Święcki (1774-1837), który ukończył Uniwersytet w Krakowie; Damazy Dzierożyński (1782-1835) w Wilnie, i najbardziej znany, wspomniany wyżej Wacław Aleksander Maciejowski (1792-1883), który kształcil się w Krakowie i Wrocławiu, a doktorat praw uzyskał w Getyndze ${ }^{3}$. Pozostałych dwunastu ukończyło Wydzial Prawa Uniwersytetu Warszawskiego, w chwili zaś zakładania „Themis" liczyli oni od 22 do 32 lat. Niektórzy z nich pogłębiali studia warszawskie za granicą. Byli to znani później prawnicy w Królestwie Polskim i poza granicami: Romuald Hube (1803-1890) ksztalcący się w latach 1823-1825 w Berlinie pod kierunkiem m.in. Savigny'ego i Hegla; August Heylman (1796-1872) studiujący w Berlinie i Getyndze; Cezary Zaborowski (1799-1866) studiujący jeszcze dwa lata w Berlinie i Paryżư ${ }^{4}$. Także w tym

${ }^{1}$ W. S obociński, Wydzial Prawa w Uniwersytecie Warszawskim (1816-1831) $i$ w Szkole Glównej (1862-1869), Warszawa 1963, s. 94-95.

${ }^{2} \mathrm{R}$. C ze pulis - R a st en is, Klassa umyslowa. Inteligencja Królestwa Polskiego (1832-1862), Warszawa 1973, s. 150.

${ }^{3}$ Slownik Biograficzny Adwokatów Polskich (SBAP), t. I/4, Warszawa 1983, s. 435-436; S. M il ew s k i, Czlowiek nie na swoje czasy, Palestra 1998, nr 7-8, s. 123-125; J. B a r d a ch, Waclaw Aleksander Maciejowski $i$ jego wspólcześni, Wrocław 1971, s. 36 in.

${ }^{4}$ W. Witkowski, Nowe pokolenie prawników Królestwa Polskiego I polowy XIX wieku, Rejent $2000, \mathrm{nr} 4$, s. 186-210. 
kontekście należy wskazać na nazwisko Aleksandra Thisa (1803-1846) - jednego $z$ najwybitniejszych studentów prawa Uniwersytetu Warszawskiego, który ukończył studia ze specjalnym indywidualnym wyróżnieniem cum eminentia et laude eximia i był uważany za wybijającą się osobowość w nowym pokoleniu prawników ${ }^{5}$. Pozostałych ośmiu wymieńmy, bowiem będzie o nich jeszcze niżej mowa. Byli to: najstarszy z nich Ignacy Maciejowski (1797-1835), a potem kolejno Karol Boromeusz Hoffman (1798-1875), Jakub Rudnicki (1800-1872), Jan Kanty Wołowski (1803-1864), Teofil Wołowski (1803-1873), Józef Hube (1804-1891), Józef Korytkowski (1805-1893) i najmłodszy Wincenty Majewski (1806-1888) redagujący ,Themis” w wieku 22 lat.

Co charakterystyczne, ośmiu $\mathrm{z}$ nich podawało szlacheckie pochodzenie społeczne, ale tylko trzech deklarowało, iż ojcowie ich mieli jeszcze własne majątki ziemskie. Inni wywodzili się już $\mathrm{z}$ rodzin oficjalistów, dzierżawców, urzędników bądź nauczycieli, a więc ze zubożałej szlachty. Następnych siedmiu pochodziło $\mathrm{z}$ grona mieszczan o zróżnicowanym statusie materialnym - od właściciela kamienicy do urzędnika. $\mathrm{Ci}$ - zarówno szlacheckiego, jak i mieszczańskiego rodowodu - generalnie nie przychodzili z domów pełnych zasobów materialnych, ale niewątpliwie nabierali przekonania o konieczności wykształcenia i możliwościach zrobienia kariery poza własnym dawnym środowiskiem. Dodać też warto, że Heylman pochodził $\mathrm{z}$ rodziny wyznania luterańskiego, This $-z$ zasymilowanej już niemieckiej rodziny Thiessów wyznania ewangelicko-reformowanego, a dwaj Wołowscy i Rudnicki reprezentowali znaczące wówczas w Warszawie liczne rodziny pochodzenia żydowskiego.

Wskazać również trzeba, z jakich kręgów zawodowych rekrutowali się redaktorzy „Themis polskiej”. Otóż trzech z nich obrało wówczas kariery akademickie $w$ Uniwersytecie Warszawskim, trzech reprezentowało sfery urzędnicze - tzn. byli oni mlodymi referentami w ówczesnych ministerstwach, a dziewięciu pracowało w wymiarze sprawiedliwości (czterech było obrońcami sądowymi, dwóch sędziami i po jednym prokuratorem, notariuszem i radcą prawnym $)^{6}$.

Reasumując, skład redakcji „Themis" wyraźnie odbijał przedstawione wyżej przemiany pokoleniowe, nowe tendencje społeczne i znaczenie wykształcenia, jak też mial wskazywać na lączenie na łamach czasopisma problemów teorii i praktyki sądowej.

\footnotetext{
${ }^{5}$ W. Witkowski, Aleksander This $i$ Jan Kanty Wolowski - wybitni prawnicy Królestwa Polskiego, Lublin 2001, passim. This doszedł do wysokich stanowisk w wymiarze sprawiedliwości Królestwa Polskiego; opublikował w Paryżu liczne prace naukowe na temat prawa w Rosji i Królestwie Polskim, będąc m.in. współpracownikiem „Revue étrangère et française de législation..." J. J. Foelixa i „Revue de législation et de jurisprudence” L. Wołowskiego.

${ }^{6}$ Por. biogramy poszczególnych prawników zamieszczone $\mathrm{w}$ odpowiednich tomach Polskiego Slownika Biograficznego i w pracy R. Ge rbe ra, Studenci Uniwersytetu Warszawskiego 1808-1831. Slownik Biograficzny, Wrocław 1977.
} 


\section{2}

Jako bezpośrednich inspiratorów utworzenia ,Themis" powszechnie wymienia się dwóch: R. Hubego - mlodego profesora prawa karnego i kanonicznego Uniwersytetu, i K. B. Hoffmana - ówczesnego radce prawnego Banku Polskiego, choć - jak wspominał tenże Hube - myśl utworzenia pisma periodycznego prawnego, poświęconego teorii i praktyce prawa, ogarnęla $w$ jednym niemal czasie kilku $z$ dawniejszych kolegów uniwersyteckich ${ }^{7}$. R. Hube miał się zająć stroną naukową czasopisma i kierowaniem redakcją, natomiast do Hoffmana należeć miało zorganizowanie materialnej strony przedsięwzięcia, tj. prawnej formy utworzenia wydawnictwa i drukarni. Zajmijmy się w tym miejscu tymi ostatnimi kwestiami.

W ówczesnej Warszawie działało 25 firm grupujących, tzn. wydawców zawodowych różnych kategorii. Byly to prywatne firmy wydawnicze, księgarskie, drukarskie i księgarsko-poligraficzne ${ }^{8}$. Założyciele „Themis” skorzystali też $\mathrm{i}$ z tej formy działalności, bowiem znaleźli wydawcę w warszawskiej firmie działającej pod nazwą: Antoni Galezowski i kompania założonej w 1827 r. Była to firmowa spółka wydawnicza posiadająca - co istotne i w Warszawie rzadkie - własną drukarnię. Spółkę tę założyło dziewięciu udziałowców, wnosząc wkłady od 1 tys. zł do 10 tys. zł w lącznej sumie 48 tys. zl, tj. 7207 rosyjskich rubli srebrnych.

Udziałowcami byli znani przedstawiciele warszawskiej inteligencji, a mianowicie: wybitny chirurg Wilhelm Malcz, profesor filozofii Uniwersytetu Warszawskiego Krystyn Lach Szyrma, adwokat Marceli Tarczewski, prawnik i teoretyk literatury Józef Dionizy Minasowicz, finansista i przemysłowiec, jeden $\mathrm{z}$ dyrektorów Banku Polskiego Henryk hrabia Lubieński i wreszcie sam wspomniany wyżej K. B. Hoffman $\mathrm{z}$ żoną - popularną pisarką i pedagogiem Klementyną $z$ Tańskich Hoffmanową . Były to osoby, które łączyło inteligenckie pochodzenie, wspólne zainteresowania naukowe $\mathrm{i}$ intelektualne, literackie dyskusje, a niektórych jeszcze związki rodzinne. W ich domach ogniskowało się zazwyczaj ówczesne życie intelektualno-towarzyskie i można przypuszczać, że właśnie w czasie takich spotkań zrodził się pomysł

${ }^{7}$ K. Du n i n, Romuald Hube (1803-1890). Studium biograficzno-bibliograficzne, Warszawa 1904, s. 23.

${ }^{8}$ Oczywiście, oprócz wydawców zawodowych cały szereg osób bądź instytucji trudnił się wydawaniem książek lub druków, co powodowało znaczące rozdrobnienie ruchu wydawniczego. Niemniej wydawcy zawodowi działający w sposób ciągly, łączący osiąganie zysku ze swej pracy $\mathrm{z}$ korzyściami ogół społeczeństwa i kultury narodowej, nadawali ton rynkowi wydawniczo-drukarskiemu. Por. M. M lekick a, Wydawcy ksiqżek w Warszawie w okresie zaborów, Warszawa 1987 , s. 29 i n.

${ }^{9}$ E. S łodk owska, Spólka wydawnicza pod firmq drukarni A. Galęzowskiego w Warszawie, Rocznik Biblioteki Narodowej [Warszawa] 1968, t. IV, s. 317-332. 
założenia spółki wydawniczej w celu upowszechniania wartościowych książek i czasopism.

Program edytorski spółki był bowiem wyraźnie zróżnicowany: od serii pism dawnych autorów polskich pod nazwą „Zbiór Pisarzy Polskich”, przez inne książki i czasopisma, po kalendarze. Funkcjonowanie spółki miało wyraźny charakter spoleczno-narodowy mający na celu, w warunkach braku polskiej państwowości, utrzymanie i upowszechnianie kultury polskiej poprzez działalność wydawniczą.

Spólka zakupila wlasną drukarnię w $1827 \mathrm{r}$. za sumę 7 tys. zl, którą firmował swoim nazwiskiem i zarządzal całym przedsiębiorstwem Antoni Gałęzowski. Po jego śmierci w 1830 r. nie zmieniono nazwy firmy, a z ramienia spólki prowadzil ją K. B. Hoffman. Drukarnia rozwijała się pomyślnie, bowiem oprócz wlasnych nakładów wykonywała stałe prace zlecone, m.in. w 1830 r. drukowała dziewięć tytułów pism codziennych i czasopism, a inwentarz za rok 1831 wykazywal 116 tytułów wydawanych pozycji. Drukarnia była też nowocześnie wyposażona, m.in. w prasy francuskie i polskie, a litery tytułowe $\mathrm{i}$ winiety sprowadzano $\mathrm{z}$ Londynu, Paryża $\mathrm{i}$ Berlina ${ }^{10}$.

W 1830 r. obok drukarni uruchomiono kantor sprzedaży wlasnych książek i odbioru prasy przez prenumeratorów, jak też książek wydawanych przez obcych nakładców otrzymanych w drodze wymiany lub oddanych w komis. Szybko też otworzono punkty sprzedaży komisowej w innych miastach Królestwa, jak też punkty prenumeraty za granicą (w Lipsku i Krakowie). Mimo więc, iż przedsięwzięcia tego podjęli się ludzie niezwiązani z księgarstwem, prosperowało ono na tyle dobrze, iż dziś ocenia się, że produkcja spółki pod firmą A. Gałęzowskiego wyróżniała się w Królestwie Polskim nie tylko pod względem ilości, ale również pod względem treści, a także stosunkowo niskich cen i znacznie przyczyniła się do ożywienia polskiego ruchu wydawniczego ${ }^{11}$. Jej powodzenie wynikało $\mathrm{z}$ faktu umiejętnego połączenia profesjonalizmu w zakresie sztuki drukarskiej $\mathrm{z}$ talentami ludzi nauki i pióra, i koneksji zawodowospołecznych (m.in. prenumeratę na wydawnictwa przyjmowali w poszczególnych miastach polskich sędziowie, lekarze czy nauczyciele).

Kres spółce wydawniczej położyło powstanie listopadowe w $1830 \mathrm{r}$., bowiem część udziałowców znalazła się na emigracji (a zwłaszcza K. B. Hoffman z żoną), a ze strony władz carskich spotykały ją represje. W $1834 \mathrm{r}$. zajęto drukarnię w sekwestr, mimo iż zatrudniała jeszcze 29 osób, a w $1837 \mathrm{r}$. wystawiono ją na licytację $i$ sprzedano za sumę 35316 rubli $^{12}$.

10 Ibidem, s. 326.

${ }^{11}$ Według prowadzonej Ksiegi dywidend, do 1830 r. rokrocznie 1 sierpnia obliczano procenty i wypłacano zyski udziałowcom. W 1828 r. wypłacono po $6 \%$, a w 1829 r. po $8 \%$, zaznaczając, iż reszta zysków zostanie przeznaczona na inwestycje; ibidem, s. 321.

${ }^{12} \mathrm{~K}$. Swierkowski, Inwentarz Drukarni A. Galezowski $i$ komp. $z$ roku 1834, Roczniki Biblioteczne 1961, t. V/4, s. 311-322. 
Tak więc personalne polączenie poprzez K. B. Hoffmana uczestnictwa w Redakcji „Themis” i w spółce wydawniczo-drukarskiej bez wątpienia przyczyniło się do możliwości utworzenia czasopisma i jego powodzenia na rynku wydawniczym. Hoffman i spólka mieli początkowo pokrywać koszty jego druku, a dalsze losy przedsięwzięcia zależały od liczby prenumeratorów, zwlaszcza że członkowie Redakcji zrzekli się honorariów tak za prace redakcyjne, jak i za zamieszczane publikacje ${ }^{13}$.

Początkowo lista prenumeratorów „Themis” wynosiła 260 pozycji, a potem nakład nieznacznie się podniósł ${ }^{14}$. Był to nakład niemały jak na czasopismo fachowe, skoro ówcześnie nakład książek w Królestwie zamykał się przeciętnie w liczbie 500 egzemplarzy ${ }^{15}$. Naturalnie zaprenumerowali je przede wszystkim prawnicy stanowiący już wówczas zwartą grupe zawodową, na którą składali się wykładowcy i studenci Wydziału Prawa Uniwersytetu, a przede wszystkim pracownicy sądowi - zarówno $w$ Warszawie - jak i na prowincji. Ogólem 1009 prawników w Królestwie do roku 1830 było prenumeratorami różnych książek i czasopism fachowych, tj. blisko połowa wszystkich, którzy w latach 1808-1830 zdobyli wyższe wykształcenie w Szkole Prawa i Nauk Administracyjnych w Księstwie Warszawskim i na Wydziale Prawa Uniwersytetu Warszawskiego (łącznie było to 2425 prawników o wyższych kwalifikacjach) ${ }^{16}$. Z imiennych danych o prenumeratorach „Themis” wynika, iż rozchodziła się ona najszerzej wśród pracowników centralnych instytucji sądowych Królestwa, a zwłaszcza wśród adwokatury, ale także wśród aplikantów, pisarzy sądowych, komorników i rejentów, i to w ośrodkach prowincjonalnych $^{17}$. Z pewnością zaważyła tu nowość czasopisma i jego prekursorski charakter, ale też dowodziło to zapotrzebowania na literaturę fachową i chęć poszerzania zdobytej wiedzy prawniczej, nie tylko wśród osób wykształconych, ale i w gronie niższych kategorii pracowników sądowych nieposiadających specjalnych kwalifikacji ${ }^{18}$.

${ }^{13}$ S. Milewski, Themis Polska - periodyk naukowców $i$ adwokatów, cz. I, Palestra 2002, nr $11-12$, s. 89.

14 Taka forma subskrypcji, powszechna w XIX w., pozwalała na dogodne warunki publikowania wielu dzieł bez szczególnego ryzyka ze strony wydawców. Poprzedzała je bowiem umowa pomiędzy wydawcą a nabywcą, niekiedy związana $z$ wcześniejszym uiszczeniem kosztów książki, pozwalająca tym samym na określenie wysokości nakładów. Por. A. D y m mel, Prenumeratorzy piśmiennictwa naukowego wydanego $w$ Królestwie Polskim w pierwszej polowie $X I X$ wieku, Lublin 1992, s. 5.

${ }^{15}$ E. Słodk owska, Spólka wydawnicza..., s. 328.

${ }^{16}$ A. D y m m el, Prenumeratorzy..., s. 26-27.

${ }^{17}$ Ibidem, s. 87-93, 145.

18 Dodać należy, iż „Themis” okazjonalnie przenumerowały szkoły średnie Królestwa, a także była ona dostępna wśród czasopism wystawianych m.in. w warszawskich kawiarniach, co mogło świadczyć o popularności czasopisma, jak i dużych talentach „marketingowych" wydawców; por. ibidem, s. 42-43 i S. M il ews ki, Themis Polska..., Palestra 2003, nr 7-8, s. 177. 
Powodzenie i rozwój „Themis" przyniosly też z początkiem $1830 \mathrm{r}$. inicjatywę w zespole redakcyjnym - odejścia od firmy $A$. Galęzowski i kompania i założenia własnej drukarni wraz $\mathrm{z}$ wydawnictwem. W tym celu opracowano i publicznie ogłoszono prospekt emisji akcji (po $100 \mathrm{zl}$ ) tak, by w efekcie powstała spółka akcyjna przejęła wydawanie i druk różnorodnych dzieł prawniczych. Nowa spółka akcyjna zapewnialaby z jednej strony odpowiednie zyski, a z drugiej - podnosiłaby w znaczący sposób rozwój kultury prawnej. Zwlaszcza że autorzy prospektu i zarazem redaktorzy "Themis" nie kryli, iż zamierzają uzyskać przychylność ówczesnej Komisji Rządowej Sprawiedliwości Królestwa Polskiego i ,zmusić” wszystkie sądy, urzędy, a nawet praktykujących prawników do obowiązkowej prenumeraty wydawanych publikacji - tak by przedsiębiorstwo funkcjonowało bez strat ${ }^{19}$. Nie znamy bezpośrednich wyników tego pomysłu, ale w dalszej perspektywie kres jemu położyło powstanie listopadowe $1830 \mathrm{r}$.

Jak już wyżej zaznaczono, myśl założenia fachowego periodyku sięgającego wzorami do niemieckiego i francuskiego odpowiednika powstala w środowisku absolwentów warszawskiego wydziału prawa. $Z$ pewnością założona w $1819 \mathrm{r}$. przez Athanazego Jourdana paryska „Themis" bezpośrednio zainspirowała polskich prawników. Uwidocznilo to się przede wszystkim w tytule pisma. W zawartości merytorycznej było już odmiennie, bowiem we francuskim czasopiśmie szerzej reprezentowane były zagadnienia teoretycznoprawne i filozoficzne. "Themis" Jourdan'a (zmarlego w 1826 r.), w czasach gdy zaczął wychodzić warszawski periodyk, mimo istotnego wpływu na francuską jurysprudencje kończyła już swe istnienie - przestała wychodzić w $1831 \mathrm{r}$.

Drugim czasopismem, które stanowiło wzór dla twórców „Themis Polskiej” był niemiecki „Zeitschrift für geschichtliche Rechtswissenschaft” ukazujący się w Berlinie od $1815 \mathrm{r}$. Byl to organ niemieckiej szkoły historycznej i w swoich zasadniczych treściach odległy od poglądów prawników polskich, niemniej część autorów piszących w „Themis” wyraźnie sięgała do tez uczonych niemieckich i próbowała je lansować w Warszawie.

„Themis Polska", choć ukazywała się krótko, szybko stała się miejscem dla różnorodnych poglądów na temat nauki prawa, roli praktyki sądowej, potrzeby reform kodeksu Napoleona i tekstów poświęconych dogmatyce prawa. Dominowala, co zrozumiale, tematyka polska, choć chętnie „Themis” informowała (m.in. w postaci przekładów) o stanie nauki prawa za granica.

Od początku $w$ zespole redakcyjnym do czołowych postaci nalezeli: Romuald Hube i Karol Boromeusz Aleksander Hoffman, a uzupełniali ich działania głównie: Aleksander This, a następnie Cezary Zaborowski, Ignacy Maciejowski oraz brat Romualda Józef Hube ${ }^{20}$. Co charakterystyczne, redakcja

\footnotetext{
19 „Themis Polska" [Warszawa] 1913, ser. II, t. II/2, s. 84-90.

${ }^{20} \mathrm{~W}$. Witk owsk i, Aleksander This $i$ Jan Kanty Wolowski..., s. 53-54.
} 
w poszycie 3 tomu VI poinformowała, iż chciałaby zwiększyć liczbę współpracowników spośród obrońców i innych prawników, by uczynić pismo bardziej użytecznym i zbliżonym „do praktyki sądowej”. Głównie jednak z grona redaktorów rekrutowali się autorzy piszący na jej lamach. Dość wspomnieć, iż we wszystkich tomach „Themis” spoza kregu redaktorskiego tylko profesor prawa cywilnego Uniwersytetu Warszawskiego Franciszek Ksawery Szaniawski opublikowal dziewięć artykułów i raz odbyła się polemika naukowa dotycząca prawa rzymskiego w Polsce między znanym historykiem J. Lelewelem a prawnikiem J. N. Janowskim ${ }^{21}$. Natomiast „głosy praktyki” prezentowali $w$ niewielkich rozprawach i doniesieniach sędziowie sądu apelacyjnego w Warszawie, prokuratorzy, adwokaci i niżsi urzędnicy sądowi. Oprócz artykułu S. Węgrzeckiego w tomie I o ustawodawstwie pruskim, pozostałe dotyczyły rozstrzygnięć sądowych i interpretacji przepisów, i znalazły się dopiero w ostatnich tomach. Powoli więc takie kwestie znajdowały miejsce w „Themis”, a redakcja informowała, iż z prawdziwq radościq pośpiesza $z$ ogloszeniem nastepnych spostrzezen praktycznych. Aby urzednicy sadowi zechcieli więcej podobnych spostrzeżen do wiadomości publicznej podawać! Pismo nasze staloby się wówczas jeszcze bardziej praktycznym, a urzędnicy wywiqzaliby sie $z$ wielkiego dostojeństwa sędziów narodu.

Przytłaczająca większość, bo przeszło 80 różnorodnych opracowań, była autorstwa redaktorów „Themis”. Oni więc, zgodnie z podtytułem, prowadzili pismo nauce i praktyce prawa poświęcone, ale ponieważ nie wszyscy zajmowali się praktyką sądową, dominowała problematyka naukowa i teoretyczna. Trzeba jednak pamiętać, że ton zespołowi redakcyjnemu nadawali ludzie młodzi, nowego pokolenia, których przede wszystkim pociągały ówczesne wielkie spory naukowe, jak i problemy bądź rozważania natury teoretycznej lub ograniczające się do egzegezy tekstów prawniczych. To ostatnie miało nader istotne znaczenie dla dostosowania francuskiego ustawodawstwa do warunków Królestwa. Przedstawiali własne często oryginalne poglądy i reprezentowali różne postawy metodologiczne. Otwierająca wydawnictwo rozprawa K. B. Hoffmana $O$ stanie nauki prawa w naszym kraju opisywala głównie w ujęciu historycznym i krytycznie dzieje polskiej nauki prawa od średniowiecza po czasy Królestwa Kongresowego, bez głębszej analizy stanu współczesnego. Wyrażał tylko Hoffman nadzieję, iż nowe środowisko prawnicze wyrosłe ze Szkoły Prawa Księstwa Warszawskiego i Uniwersytetu otworzy $w$ mlodzieży poped do szukania slawy $w$ glebszym rozebraniu teorii $i$ slużeniu

\footnotetext{
${ }^{21}$ F. K. Szaniawski przede wszystkim w t. I (poszycie 3) przedstawił swój Wyklad ksiegi pierwszej cywilnego kodeksu Królestwa Polskiego (s. 232-247), a następnie artykuły z prawa zobowiązań, małżeńskiego i spadkowego, w ujęciu dogmatycznym, a także Historyczny wywód jakim sposobem sobór trydencki przyjety byl w Polsce (t. VII, p. 4, s. 351-370). Polemika Lelewela $\mathrm{z}$ Janowskim wynikła $\mathrm{z}$ opublikowanej przez tego ostatniego konkursowej pracy w Uniwersytecie Warszawskim (t. I, p. 2, s. 97-139 i t. II, p. 2, s. 101-110).
} 
bardziej nauce niż urzedom, skłaniając do porzucenia kazuistyki na rzecz naukowego prawoznawstwa ${ }^{22}$.

Stąd też profil „Themis”, niezakreślony właściwie na wstępie przez Redakcję, ksztaltował się w sposób dość żywiołowy, choć z pewnością zashugą przede wszystkim Hubego było w miarę konsekwentne utrzymywanie wewnętrznego układu pisma według zasadniczych działów: prawodawstwa, historii prawa, prawa cywilnego i kryminalnego ( $\mathrm{z}$ pewnymi modyfikacjami zależnie od otrzymywanych materiałów). Ilościowo znacznie przeważały prace z zakresu cywilistyki. Było to niewątpliwie konsekwencja recypowania francuskiego ustawodawstwa, ale też wyrazem rozwoju ekonomicznego Królestwa Polskiego $\mathrm{i}$ wiązało się z kształtowaniem stosunków kapitalistycznych wpływających jednocześnie na rozwój nowych instytucji prawa i postępowania cywilnego ${ }^{23}$.

Aleksander This bez wątpienia od razu stał się jednym $\mathrm{z}$ filarów "Themis” i jego twórczość istotnie wpłynęła na profil i ocenę czasopisma. Przede wszystkim był najpłodniejszym autorem spośród wszystkich piszących trzynastu redaktorów ,Themis". Zamieścil w niej łącznie 20 prac naukowych, a więc dostarczył okolo $1 / 4$ wszystkich prac opublikowanych przez członków redakcji. Dla porównania, następny po nim, R. Hube zamieścił 12 publikacji, a C. Zaborowski - dziesięć. Po nich, po ponad pięć prac opublikowali: K. B. Hoffman, A. Heylman, J. Hube i J. K. Wołowski, a z grona pozostałych: Ignacy Maciejowski - cztery, J. Rudnicki - trzy, T. Wołowski - dwie, i po jednej: D. Dzierożyński, W. A. Maciejowski oraz J. Mędrzecki.

Dlatego też wydaje się celowe w tym miejscu wskazać charakterystyczne cechy twórczości Thisa na łamach „Themis” porównawczo z publikacjami innych autorów, gdyż w jego pisarstwie odnaleźć możemy wątki nowatorskie, ale również poszukiwania naukowe co do postawy metodologicznej i filozofii badawczej. „Themis” istniała zbyt krótko, by autorzy w niej piszący (i to w gronie samego zespołu redakcyjnego) mogli wykrystalizować i próbować ujednolicić swe poglądy, zwlaszcza wobec tak istotnych kwestii, jak relacje między prawem narodowym a obcym w warunkach polskich czy wspólne odniesienie do szkoly historycznej lub francuskiej filozofii prawa. Dlatego właśnie spojrzenie poprzez publikacje Thisa określi nam w znacznej mierze wartość „Themis” dla nauki i ówczesnego środowiska prawników polskich.

${ }^{22}$ T. I, p. 1, s. 1-30. Piszqqc historię nauki prawa w naszym kraju, trzeba pisać nie historie jej wzrostu ale historie przeszkód $z$ którymi walczyla $i$ wreszcie upadku; s. 10. Por. też: W. S obocin ski, Wydzial Prawa..., s. 94.

${ }^{23}$ S. Milewski, Themis Polska..., Palestra 2003, nr 1-2, s. 106. 
Potrafił This, mimo obowiązków zawodowych i podróży zagranicznych, efektywnie pracować naukowo, a jego talent pisarski, szybko tworzyć. Jego dorobek w „Themis" powstal w ciągu niecałych trzech lat.

\section{4}

Drugą, ogólniejszą cechą ówczesnej twórczości Thisa była różnorodność podejmowanych tematów i swoboda, $\mathrm{z}$ jaką poruszal się w rozmaitych gałęziach prawa, aczkolwiek szeroko rozumiana cywilistyka stała się u niego wyraźnie dominująca $i \mathrm{w}$ jej ramach zostal on niekwestionowanym autorytetem. $\mathrm{Na}$ dwadzieścia jego merytorycznych rozpraw i artykułów, dziesięć dotyczyło prawa cywilnego i handlowego Królestwa, a sześć - współczesnej procedury cywilnej. Ponadto jeden raz zajął się dawnym polskim prawem spadkowym, ale w kontekście jego obowiązywania w Królestwie. Prawu karnemu Królestwa poświęcił jedno opracowanie, a zagadnieniom prawno-teoretycznym - dwa obszerniejsze studia.

Gdybyśmy chcieli generalnie porównać jego pisarstwo $\mathrm{z}$ twórczością innych wybitnych autorów „Themis”, to różnice staną się wyraźne, przede wszystkim w odniesieniu do R. Hubego i jego częstego adwersarza A. Heylmana, jak też J. Hubego czy K. B. Hoffmana. Wszyscy wymienieni, obok zajmowania się prawem obowiązującym, więcej miejsca poświęcali historii prawa i problematyce jego nauki, jak też prawodawstwa. Wystarczy tu wspomnieć obszerne trzy studia R. Hubego zapoczątkowane artykułem $O$ stanie nauki prawa $w$ naszych czasach i polemiczne wystapienia A. Heylmana będące $w$ istocie zasadniczą dyskusją na temat zalet i wad szkoły historycznej i tzw. filozoficznej szkoły prawa w Niemczech, czy też francuskich konstrukcji kodeksowych i jurysprudencyjnych ${ }^{24}$. Tak samo na stronach „Themis" toczył się spór o wartość dawnego polskiego prawa spadkowego i kodeksowego francuskiego, a obydwaj Hubowie publikowali na temat dziejów instytucji francuskich prokuratorów, dawnych zbiorów praw czeskich, wpływów prawa rzymskiego na prawodawstwo francuskie i prawa spadkowego wśród Słowian.

A. This nie brał w tym nurcie rozważań w ogóle udziału, zwłaszcza obce były mu wówczas studia historyczno-prawne. Natomiast swoją twórczością zdecydowanie wypełnial „dogmatyczną” część czasopisma, idąc za swoim

${ }^{24}$ Rozprawa R. H u beg o $O$ stanie nauki... znalazła się w t. III, p. 1, s. 1-17, i pisana była w grudniu 1827 r., a dwie kolejne Uwagi nad systematem kodeksu cywilnego francuskiego i Niektóre uwagi nad historiq nauki prawa ukazały się w 1829 i 1830 r., t. V, p. 3, s. 297-339; t. VII, p. 2, s. 157-207. A. Heylman swoje stanowisko przedstawił w dwóch pracach z 1830 r.: Wywód zasad ogólnych nauki prawa i prawodawstwa (t. VII, p. 1, s. 1-55) oraz Myśli o nauce prawa i prawodawstwie w kraju naszym (t. VII, p. 2, s. 109-144). 
uniwersyteckim profesorem prawa cywilnego Franciszkiem Ksawerym Szaniawskim (1768-1830). W tej mierze This zostal z pewnością najwybitniejszym uczniem Szaniawskiego. Szaniawski nie był wyłącznie dogmatykiem prawa, o czym świadczą jego liczne studia teoretyczno-porównawcze z nawiązywaniem do koncepcji prawa naturalnego, ale właśnie na lamach „Themis" zamieścil parę prac dotyczących prawa obowiązującego pisanych metodą dogmatyczną.

Patrząc na twórczość Thisa w tym okresie i szukając jej inspiracji w kręgu nauczycieli akademickich, wskazać więc należy na Szaniawskiego, a szczególnie na predylekcję tego ostatniego do kodeksu Napoleona i francuskiej szkoły prawa ${ }^{25}$. To oczywiście przejął This wyłącznie na gruncie cywilistyki. $Z$ drugiej strony, śmiałe wkraczanie w różne dziedziny prawa świadczyło o samodzielności i ambicjach twórczych Thisa, a poparte było, oprócz rzetelnej wiedzy z czasów studiów, pogłębionym później samokształceniem zwłaszcza w literaturze naukowej. Pamiętać należy - o czym już była mowa - iż This kształcił się wyłącznie w kraju, a więc przede wszystkim studia uniwersyteckie dały mu szerokość horyzontów myślowych.

Drugim profesorem, którego działalność odbila się na zainteresowaniach Thisa, pozostal wykładający na studiach administracyjnych Fryderyk Skarbek (1792-1866). Dzięki odbytym u niego studiom This nie tylko znakomicie radził sobie zawodowo $w$ sądownictwie administracyjnym, ale również mógł wystąpić z gruntownym i prekursorskim opracowaniem trudnej problematyki sądownictwa kompetencyjnego ${ }^{26}$. Najbliżej Thisa, poza J. K. Wołowskim, na forum „Themis" uprawiany przez niego typ twórczości naukowej prezentowal C. Zaborowski, który oprócz pracy $O$ restytucji $i$ kasacji (też wywodu historyczno-dogmatycznego, jak sam zaznaczal) zamieścil parę innych analitycznych publikacji z zakresu prawa cywilnego Królestwa ${ }^{27}$.

${ }^{25} \mathrm{O}$ poglądach Szaniawskiego por. W. S obociński, $Z$ zagadnień myśli polityczno-prawnej polskiego Oświecenia, [w:] Wiek XVIII. Polska i Świat, Warszawa 1974, s. 323-328. W. Sobociński akcentuje wpływy Szaniawskiego na twórczość D. Dzierożyńskiego i profesora Uniwersytetu Wileńskiego I. D a n i łow icza - autora opracowanej w 1818 r. pracy Kodeks Napoleona $w$ porównaniu z prawami polskimi i litewskimi (wyd. A. Kraushar, Warszawa w 1905), jak też na przedstawicieli młodego pokolenia W. Dutkiewicza, A. Thisa, J. K. Wołowskiego i C. Zaborowskiego.

${ }^{26}$ Może nie był to wpływ bezpośredni, ale zainteresowanie problematyką prawa publicznego i administracji wraz z nauką policji oraz linansowo-ekonomiczną. Skarbek był wówczas jedynym profesorem na studiach administracyjnych $\mathrm{i}$ wykładał wszystkie przedmioty. Tylko This i Holfman podjęli na łamach „Themis”, czy szerzej w środowisku warszawskim, tematykę spoza prawa sądowego. Pierwszy w rozprawie $O$ sporach jurysdykcyjnych (t. VIII, p. 1, s. 261-368), a drugi w artykule $O$ stanie sqdownictwa administracyjnego $w$ naszym kraju (t. VII, p. 4, s. 277-305).

${ }^{27}$ Praca $O$ restytucji znalazła się w t. VIII, p. 1, s. $25-56$ i p. 2, s. 141-176. 
Z lektury tekstów Thisa zamieszczonych $\mathrm{w}$ „Themis” nie można jasno i wyraziście wysnuć jego ówczesnego stanowiska naukowego, choć da się określić pewne istotne elementy jego ówczesnych zapatrywań. Nie zabrał głosu, gdy rówieśnik Hube określał swoje poglądy, opowiadając się za narodowym prawodawstwem cywilnym w miejsce kodeksu Napoleona, a oceniając wysoko znaczenie badań historycznych uważał, iż prawo powstaje w drodze ustaw i winno slużyć praktyce sądowej i potrzebom życia. Reprezentował tym samym Hube nurt krytyczny w szkole historycznej, raczej zbliżony do myśli niemieckiej wywodzącej się od Hegla i jego ucznia E. Gansa ${ }^{28}$. Nie podjął też This dialogu z A. Heylmanem przedstawiającym się jako zwolennik szkoły historycznej, choć też nie w pełni konsekwentnie, skoro znajdował walory jurysprudencji francuskiej i metody egzegetycznej. Milczenie to nie oznaczało jednak braku jakichkolwiek poglądów. Oznaczało z pewnością, iż This odrzucal już wówczas tezy szkoły historycznej, natomiast mogly być mu bliższe poglądy Hubego.

Idąc od początku własną drogą, This uznawał, iż ma nie do końca jeszcze wykrystalizowane stanowisko naukowo-teoretyczne, wyraźnie mieszczące się $w$ tej czy innej szkole filozoficznej. Tak by wynikało $z$ analizy jego prac dogmatycznych, w których można tylko „wyłowić” myśli ogólniejsze, będące odniesieniem do profilu „Themis” i prezentujące postawę badawczą autora. Z pewnością samo wysunięcie na plan pierwszy współczesnej tematyki cywilistycznej dowodziło szczególnego zainteresowania ustawodawstwem francuskim na gruncie polskim. $Z$ drugiej strony nie domagal się This wprowadzania ustawodawstwa narodowego i wydaje się, że nie bylo to dla niego rzeczą aż tak istotną. Należał This w czasach konstytucyjnych Królestwa do tych obrońców kodeksu Napoleona, którzy wstrzymywali zamysly polskich prawników pragnących powrotu do kodyfikacji narodowej, ale z utrzymywaniem stosunków feudalnych zwłaszcza w zakresie prawa rzeczowego ${ }^{29}$. This wysuwal, i to należy podkreślić, na główne miejsce praktyczną użyteczność tekstu ustawowego dla wymiaru sprawiedliwości. Jego dogmatyczne rozważania, niekiedy ograniczone do analizy paru artykułów kodeksowych i dające ścisłą interpretację natury formalnej, miały doprowadzać do jednoznacznego stosowania norm kodeksowych.

${ }^{28}$ Zdecydowanie R. Hube akcentował w polskich warunkach, znaczenie praktyki sądowej, bowiem tylko ona może pogodzić przepisy kodeksowe z życiem narodu. Podkreślał też, że mimo ponad 20 lat funkcjonowania kodeksu Napoleona w literaturze polskiej brak komentarzy orzeczeń, opracowań, a nawet jakichkolwiek odniesień do orzecznictwa sądowego (,Themis”, Uwagi..., t. V, p. 3, s. 310-313).

${ }^{29}$ Por. W. Sobociński, Prawo francuskie $w$ Niemczech aw Polsce (nowe opracowania niemieckie recepcji i refleksje porównawcze), Annales UMCS 1982, sec. F, vol. 37, s. 181-183. 
W jednej z prac z 1829 r. This zdecydowanie wskazal, iż w „Themis” wierni pobudkom, którym pismo nasze swój byt zawdziecza, mając ciagle na bacznej uwadze rozprzestrzenienie praktycznej onego [tj. prawa - W. W.] użyteczności $i$ dosiegnięcie przez to jednego z glównie zamierzonych celów, staramy się zbierać i rozjaśniać takie wypadki, które codziennie zajmujac sqdownicze magistratury, przez rozdwojenie jakie $w$ zdaniach prawników zradzajq sie, sq dla nas zachęta a niemal wkladajac obowiazek troskliwego nad nimi zastanowienia sie $^{30}$. Ten rodzaj publikacji leżał $w$ temperamencie pisarskim Thisa i stał się jego domeną, choć przecież nie wychodzily one spod ręki praktyka-prawnika $w$ rozumieniu funkcjonariusza aparatu sprawiedliwości w sądownictwie powszechnym, a urzędnika o ambicjach naukowych. Zwracał także w innym miejscu This uwage, iż ograniczanie się tylko do analiz orzeczeń sądowych, jakkolwiek tak ważne dla praktyki, to stanowczo za mało, by dobijać sie o szczytna prudenta [uczonego - W. W.] godnośc $c^{31}$. Osiągnie się ją wówczas, gdy przede wszystkim dążyć się będzie do prawdy, a w nauce prawa, na podstawie materiału praktycznego, autor będzie potrafił ustalić i wskazać ostateczną regułę postępowania dla stosujących normy prawne. Tylko bowiem przez wskazanie wiaściwego stanowiska $i$ wyjednanie nań powszechnej $w$ świecie prawniczym zgody przyznamy badaniom naszym jakażkolwiek użyteczność - pisal This w $1828 \mathrm{r}^{32}$ Ta użyteczność zarówno przy podejmowaniu tematyki badawczej, jak i przy przedstawianiu twierdzeń ostatecznych miała być głównym motywem pracy twórczej, popartej zawsze obowiązkiem zajęcia wlasnego stanowiska wobec omawianego zagadnienia ${ }^{33}$. Powtarzał dalej This za Hubem, iż w nauce lepiej jest zawsze zaufawszy sile wlasnego rozumowania utworzyć ciqg mocnych samoistnych dowodzeń niż opierać sie tylko na powadze znakomitych pisarzy ${ }^{34}$. Dowodziło to wiary we własną wiedzę, umiejętności i ambicje w dążeniu do realizacji stawianych celów. W nauce nie ma punktu spocznienia albo się cofać, albo naprzód kroczyć potrzeba - ogłosił This w 1829 r. na łamach „Themis” i konsekwentnie trzymal sie tej dewizy w swojej twórczości ${ }^{35}$.

Historia prawa i cywilistyka w ujęciu dogmatycznym to niewątpliwie dwa główne nurty przebijające $w$ twórczości prezentowanej na lamach „Themis". Ich dominanta wydaje się w pelni uzasadniona $i$ zrozumiala.

${ }^{30}$ „Themis”, t. V, p. 3, s. 401.

${ }^{31}$ Ibidem, t. VI, p. 3, s. 381.

${ }^{32}$ Ibidem, t. I, p. 3, s. 217.

${ }^{33}$ Tym należy wytłumaczyć różnorodność zainteresowań Thisa, bowiem sięgając do nowych i oryginalnych tematów, np. z przepisów stemplowych, wekslowych czy egzekucyjnych, uważał, iż ich podjęcie, a tym bardziej rozwiązanie da wymierne korzyści praktyce. Pozbawione natomiast tych walorów rozprawy filozoficzno-historyczne, aczkolwiek ważne, nie pociągały jeszcze wówczas Thisa.

34 "Themis", t. VI, p. 2, s. 234-235.

${ }^{35}$ Ibidem, t. VI, p. 3, s. 381. 
Pierwszy nurt nawiązywał do szkoły historycznej i w tym kontekście doszukiwał się wartości dawnego prawa polskiego i możliwości jego jeszcze stosowania w programie prac kodyfikacyjnych, żywo prowadzonych w Królestwie Polskim w latach 1815-1830. Drugi, bliżej tu scharakteryzowany, wskazywał głównie na nieuchronność przemian w prawie związanych ze stosunkami gospodarczymi i społecznymi, i na zalety wprowadzonego w Księstwie Warszawskim ustawodawstwa francuskiego, a szczególnie cywilnego kodeksu Napoleona z 1804 r. Niewątpliwie „Themis Polska” stała się pierwszą publiczną trybuną dla różnorakich poglądów i przez to zyskala trwałe miejsce w dorobku polskiej myśli prawniczej. Twórczość Aleksandra Thisa uprawiana na jej łamach jest też tego niezaprzeczalnym potwierdzeniem. 